\title{
Pengembangan dan Validasi Instrumen Pengukuran Efektivitas Tim di Usaha Mikro Kecil dan Menengah (UMKM)
}

\author{
Faradilla ledliany, ${ }^{1}$ Arief Fahmie, ${ }^{2}$ Elisa Kusrini ${ }^{3}$ \\ ${ }^{1,2}$ Fakultas Psikologi dan IImu Sosial Budaya, ${ }^{3}$ Fakultas Teknologi Industri Universitas Islam Indonesia, \\ Yogyakarta - Indonesia
}

\begin{abstract}
In general, research on the development of teamwork-measuring instruments is associated with the corporate context. While in Indonesia, research in the context of small and medium enterprises is equally important. This study aimed to develop and validate an instrument for measuring team effectiveness in small and medium enterprises (SMEs). The development of this measuring instrument used the theory developed by Cantu (2007) which consists of six aspects, namely teamwork, decision making, leadership support, trust and respect, recognition and appreciation, and customer focus. Research respondents were 404 employees from thirteen SMEs situated in Yogyakarta, who were selected by using purposive sampling technique. EFA analysis resulted in $\mathrm{KMO}=.821$, indicating a reduction of the aspects from six to three: decision making, leadership support, and trust. While from the CFA analysis were obtained the values of $\mathrm{CMIN}=116,566$, probability .057 , CMIN/DF=1.240, GFI= .932, RMSEA $=.034$ so that it could be concluded that the model have been appropriate to measure the effectiveness of teamwork in small and medium enterprises.
\end{abstract}

Keywords: confirmatory factor analysis (CFA); exploratory factor analysis (EFA); team effectiveness

\begin{abstract}
Abstrak: Pada umumnya, penelitian tentang pengembangan alat ukur kerjasama tim dikaitkan dengan konteks perusahaan. Sementara di Indonesia, penelitian dalam konteks Usaha Mikro Kecil dan Menengah (UMKM) tidak kalah penting. Penelitian ini bertujuan mengembangkan dan memvalidasi alat ukur efektivitas tim di UMKM. Pengembangan alat ukur ini berdasarkan teori dari Cantu (2007) yang terdiri dari enam aspek, yaitu kerja tim, pengambilan keputusan, dukungan kepemimpinan, kepercayaan dan penghormatan, pengakuan dan penghargaan, dan fokus pelanggan. Responden penelitian adalah 404 karyawan dari 13 UMKM di Yogyakarta dengan menggunakan teknik purposive sampling. Dari hasil analisis EFA diperoleh nilai KMO sebesar 0,821 dan menunjukkan perubahan aspek yang semula memiliki enam kemudian berubah menjadi tiga: pengambilan keputusan, dukungan kepemimpinan, dan kepercayaan. Sementara dari hasil analisis CFA diperoleh nilai CMIN $=116,566$, probabilitas 0,057, CMIN/DF 1,240, GFI sebesar 0,932, RMSEA sebesar 0,034, sehingga dapat disimpulkan model telah fit untuk mengukur efektivitas tim di UMKM.
\end{abstract}

Kata Kunci: confirmatory factor analysis (CFA); exploratory factor analysis (EFA); efektivitas tim

Corresponding Author: Faradilla ledliany (e-mail: raiera1206@gmail.com). Program Studi Magister Psikologi Profesi Fakultas Psikologi dan IImu Sosial Budaya Universitas Islam Indonesia, Jl. Kaliurang KM. 14,5 Sleman Yogyakarta 55584. 


\section{Pendahuluan}

Pengukuran efektivitas tim adalah isu krusial. Hal ini disebabkan efektivitas tim sangat penting bagi keberhasilan organisasi, karena tidak semua tim mampu mencapai efektivitas dan produktivitas tim yang tinggi (Buzaglo \& Wheelan, 1999). Tim menjadi salah satu bagian yang memberikan pengaruh besar dalam keberhasilan organisasi. Adanya tim kerja dianggap sebagai respon yang efektif terhadap proses kerja organisasi (Mohanty \& Mohanty, 2018). Tim akan menghasilkan keputusan yang lebih berkualitas dibandingkan dengan keputusan yang diambil secara individu (Cantu, 2007). Tim merupakan sekumpulan individu yang memiliki beragam keterampilan, keahlian, dan pengalaman. Pekerjaan yang dikerjakan dengan tim lebih mudah untuk mencapai tujuan daripada bekerja secara mandiri (Pratiwi \& Nugrohoseno, 2014).

Efektivitas tim dilihat sebagai keluaran dari hasil perilaku anggota tim. Komponen utama dalam efektivitas tim adalah kinerja kelompok, kepuasan anggota, dan kemampuan tim dalam bertahan menjadi bagian dari tim tersebut. Tim yang efektif dapat dilihat dan diukur berdasarkan bagaimana tim mampu untuk mencapai tujuannya dan menghasilkan kinerja yang optimal. Efektivitas tim memberikan keuntungan bagi perusahaan dalam meningkatkan kualitas, fleksibilitas, koordinasi, dan produktivitas dari perusahaan (Cantu, 2007).

Penelitian tentang pengembangan alat ukur sebelumnya sudah pernah beberapa kali dilakukan oleh peneliti terdahulu. Salah satunya adalah penelitian yang dilakukan van Roosmalen (2012) tentang pengembangan alat ukur kerja sama tim dengan menggunakan model the big five of team work dan berdasarkan teori yang dikembangkan oleh Salas dan Hackman. Hasil dari penelitian tersebut menunjukkan bahwa delapan faktor yang dikemukakan oleh Salas dan Hackman memiliki hasil yang valid. Penelitian pengembangan alat ukur juga dilakukan oleh Cantu (2007) dengan menggunakan 12 dimensi dalam pembuatan alat ukur, yaitu komunikasi, pengambilan keputusan, kinerja, customer focus, rapat tim, continuous improvement, penanganan konflik, kepemimpinan, pemberdayaan, trust, kohesivitas atau hubungan tim, pengakuan dan imbalan. Hasil analisis dari penelitian tersebut membentuk enam faktor yang mengukur efektivitas tim, yaitu kerja tim, pengambilan keputusan, dukungan kepemimpinan, kepercayaan dan penghormatan, pengakuan dan imbalan, dan fokus pelanggan. Faktor yang diperoleh menunjukkan konsep dimensi yang telah valid sebagai faktor pembangun efektivitas tim. Penelitian pengembangan alat ukur efektivitas tim sebelumnya dilakukan pada konteks perusahaan sementara penelitian pengembangan alat ukur efektivitas tim yang berfokus pada Usaha Mikro Kecil dan Menengah atau UMKM di Indonesia masih belum pernah dilakukan. UMKM memiliki proses kerja dan latar belakang karyawan yang berbeda dengan perusahaan besar dan merupakan pelaku ekonomi yang mayoritas.

Pengukuran efektivitas tim pada sebuah perusahaan sangatlah penting. Melalui pengukuran perusahaan dapat mengetahui kondisi sesungguhnya yang ada di perusahaan. Seperti yang dikemukakan Hexmoor \& Beavers (2002) adanya hasil pengukuran dapat digunakan sebagai bahan evaluasi untuk pengembangan dan peningkatan dalam pencapaian tujuan kelompok ataupun organisasi. Selain itu, menurut Cantu (2007) hasil pengukuran efektivitas dapat digunakan perusahaan untuk memperoleh hasil dari investasi biaya yang telah digunakan untuk mendukung struktur tim kerja, sehingga perusahaan mengetahui bagaimana efektivitas tim kerja.

Efektivitas merupakan kemampuan untuk mencapai tujuan yang telah ditetapkan dengan cara menyelesaikan pekerjaan secara efektif dan 
efisien (Sudirman, 2013). Robbins dan Judge (2015) menjelaskan bahwa tim terdiri dari dua orang atau lebih yang saling berhubungan dan saling bergantung satu sama lain dengan maksud untuk mencapai tujuan bersama. Cantu (2007) mengemukakan bahwa tim kerja sebagai sekelompok individu yang saling berkaitan satu sama lain dengan keterampilan yang saling melengkapi untuk bersama-sama berkontribusi dalam mencapai tujuan. Cantu (2007) dalam penelitiannya mengemukakan efektivitas tim adalah sejauh mana hasil yang ditunjukkan dari kinerja tim serta proses yang dilakukan oleh anggota tim dalam mencapai tujuan.

Menurut Cummings \& Worley (2008) efektivitas tim dapat dilihat dari input, design component, dan output yang dihasilkan oleh tim. Adapun aspek-aspek dalam design component ada enam. Pertama, kejelasan tujuan (goal clarity), yaitu seberapa baik tim dapat mengerti dengan tujuan tim yang akan dicapai. Adapun secara umum, dapat dilakukan melalui pengukuran, memonitor, dan pemberian umpan balik tentang informasi mengenai pencapaian target. Kedua, struktur tugas (task structure), yaitu cara tim dalam bekerja dilihat dari struktur tugas pada divisi tersebut. Struktur tugas memiliki dua kunci utama, yaitu bagaimana usaha koordinasi antar anggota dalam tim dan bagaimana regulasi dari pembagian tugas-tugas anggota. Ketiga, komposisi tim (group composition), yaitu tim kerja yang dapat dilihat dari perbedaan umur, pendidikan, pengalaman, keterampilan serta kemampuan yang bisa mempengaruhi bagaimana individu berperilaku dan berinteraksi dalam tim. Keempat, fungsi tim (group functioning) yaitu dinamika tim dalam bekerja dilihat dari sejauh mana tiap-tiap anggota berhubungan atau berkomunikasi dengan anggota yang lain di dalam tim kerja, karena hubungan yang baik antar anggota dapat memberikan efek pada performansi tugas yang baik. Terakhir, norma kinerja (performance norms), yaitu kepercayaan anggota mengenai bagaimana tim seharusnya dalam melakukan tugas. Norma berasal dari interaksi antar anggota, yang berfungsi sebagai panduan bagi tim dalam berperilaku. Penelitian yang dilakukan oleh Cantu (2007) menghasilkan enam dimensi untuk mengukur efektivitas tim. Adapun enam dimensi tersebut, yaitu kerja tim, pengambilan keputusan, dukungan kepemimpinan, keepercayaan dan penghormatan, pengakuan dan penghargaan, dan fokus pelanggan.

Berdasarkan paparan sebelumnya, maka dapat dilihat bahwa adanya pengukuran efektivitas tim diperlukan dalam proses pengembangan UMKM. Adanya pengukuran terhadap efektivitas tim dapat membantu UMKM untuk melihat dan mengevaluasi seberapa efektif kinerja dari setiap tim yang ada di UMKM tersebut. Penelitian ini berfokus untuk pengembangan dan validasi alat ukur efektivitas tim, sehingga alat ukur yang dihasilkan dari penelitian nantinya dapat digunakan sebagai dasar dalam proses pengembangan.

\section{Metode}

Populasi pada penelitian ini adalah karyawan UMKM dari industri kreatif. Terdapat 2.500 orang karyawan UMKM yang terdaftar di Dinas Perindustrian dan Koperasi DIY. Responden dalam penelitian adalah 404 orang karyawan UMKM yang diperoleh dari tiga belas UMKM di kota Yogyakarta dan Bantul. Penentuan responden menggunakan teknik purposive sampling. Adapun kriteria responden penelitian ini adalah karyawan UMKM, berjenis kelamin laki-laki dan perempuan, semua usia, dengan masa kerja minimal satu tahun.

Teknik pengumpulan data pada penelitian ini dengan menggunakan kuesioner/skala. Penelitian ini merupakan pengembangan alat ukur, sehingga ada beberapa prosedur pembuatan konstruk yakni mengidentifikasi tujuan alat ukur, pembatasan domain, operasionalisasi aspek, pe- 
Table 1.

Blue Print Skla Efektivitas Tim

\begin{tabular}{|c|c|c|c|c|c|}
\hline No. & Aspek & Indikator Perilaku & $\begin{array}{l}\text { Item } \\
\text { favorable }\end{array}$ & $\begin{array}{l}\text { Item } \\
\text { unfavorable }\end{array}$ & $\begin{array}{l}\text { Jumlah } \\
\text { Item }\end{array}$ \\
\hline 1 & Kerja tim & $\begin{array}{l}\text { a. Berbagi informasi antar anggota tim } \\
\text { b. Menyelesaikan masalah dengan efektif } \\
\text { c. Anggota tim saling mendukung } \\
\text { d. Adanya nilai dalam tim }\end{array}$ & $\begin{array}{l}2,3,4,5 \\
7\end{array}$ & 1,6 & 7 \\
\hline 2 & $\begin{array}{l}\text { Pengambilan } \\
\text { Keputusan }\end{array}$ & $\begin{array}{l}\text { a. Mengidentifikasi permasalahan bersama } \\
\text { b. Bekerja sama dalam mengambil keputusan } \\
\text { c. Adanya proses evaluasi dalam mengambil } \\
\text { keputusan } \\
\text { d. Proses mengumpulkan perspektif dari } \\
\text { semua anggota tim }\end{array}$ & $8,10,11$ & $9,12,13,14$ & 7 \\
\hline 3 & $\begin{array}{l}\text { Dukungan } \\
\text { kepemimpinan }\end{array}$ & $\begin{array}{l}\text { a. Atasan memberikan umpan balik kinerja } \\
\text { terhadap kinerja karyawan. } \\
\text { b. Atasan memastikan sumberdaya yang } \\
\text { diperlukan tim dalam menjalankan } \\
\text { pekerjaan. } \\
\text { c. Pengembangan keterampilan tim melalui } \\
\text { pembinaan } \\
\text { d. Adanya kolaborasi antara pemimpin dan } \\
\text { tim } \\
\text { e. Pemberdayaan tim yang dilakukan } \\
\text { pemimpin }\end{array}$ & $\begin{array}{l}15,16 \\
17,19 \\
21,23\end{array}$ & $18,20,22$ & 9 \\
\hline 4 & $\begin{array}{l}\text { Trust dan } \\
\text { Respect }\end{array}$ & $\begin{array}{l}\text { a. Konsistensi dan rasa hormat antar anggota } \\
\text { tim } \\
\text { b. Keterbukaan antar anggota tim } \\
\text { c. Kejujuran antar anggota tim }\end{array}$ & $\begin{array}{l}24,25 \\
27\end{array}$ & $26,28,29$ & 6 \\
\hline 5 & $\begin{array}{l}\text { Recognition } \\
\text { dan Reward }\end{array}$ & $\begin{array}{l}\text { a. Adanya penghargaan dan pengakuan } \\
\text { dalam tim } \\
\text { b. Efektivitas penghargaan dan pengakuan }\end{array}$ & $\begin{array}{l}31,32 \\
33,34\end{array}$ & 30 & 5 \\
\hline 6 & $\begin{array}{l}\text { Fokus } \\
\text { Pelanggan }\end{array}$ & $\begin{array}{l}\text { a. Memberikan pelayanan yang baik untuk } \\
\text { memenuhi kebutuhan pelanggan. } \\
\text { b. Mampu memahami kebutuhan dan } \\
\text { harapan pelanggan } \\
\text { c. Berusaha mencari umpan balik yang } \\
\text { diberikan pelanggan untuk perbaikan } \\
\text { kinerja tim. } \\
\text { d. Hubungan yang baik dengan pelanggan. }\end{array}$ & $\begin{array}{l}35,37 \\
38,39\end{array}$ & 36,40 & 6 \\
\hline \multicolumn{5}{|c|}{ Total } & 40 \\
\hline
\end{tabular}

nulisan item, uji coba bahasa, field test (evaluasi kuantitatif), seleksi item, estimasi reliabilitas, validitas konstruk, dan kompilasi final (Azwar, 2013).

Adapun proses analisis dilakukan dengan metode Exploratory Factor Analysis atau EFA dan Confirmatory Factor Analysis atau CFA (Widodo, 2006). Pengujian reliabilitas dilakukan dengan menggunakan construct reliability (CR) sedang- kan validitas yang digunakan adalah validitas isi dan validitas konstruk.

Penelitian ini mengadaptasi skala efektivitas tim dari penelitian Cantu (2007). Skala efektivitas tim yang dibuat berjumlah 40 item yang terdiri dari 25 item positif dan 15 item negatif. Item pada skala penelitian ini disajikan dalam bentuk pernyataan pilihan. Penilaian skala efektivitas 
tim menggunakan skala Likert dengan lima pilihan respon yaitu sangat tidak setuju (STS), tidak setuju (ST), netral (N), setuju (S), sangat setuju (SS), dengan range skor pada item positif adalah 1-5 dan negatif 5-1. Berikut rincian skala efektivitas tim yang dapat dilihat pada Tabel 1 .

\section{Hasil}

Responden dalam penelitian ini sebanyak 404 orang yaitu 200 responden untuk analisis EFA dan 204 responden untuk analisis CFA. Rincian responden untuk analisis EFA dalam Tabel 2. Pada Tabel 2 dapat dilihat dari 200 responden karyawan didominasi perempuan $(54,5 \%)$. Usia responden didominasi dari rentang 34-42 tahun sebanyak 62 orang (31\%). Kategori masa kerja dari rentang 1-9 tahun memiliki persentase terbesar yaitu 70,5\% (141 orang). Pada kategori pendidikan persentase ter- besar berada pada pendidikan SMA/MA dengan persentase $59,50 \%$ (119 orang) sementara yang terendah pada pendidikan SD/MI sebanyak 14 orang dengan persentase $7 \%$. Rincian responden untuk analisis CFA sebagaimana dalam Tabel 3.

Tabel 3 merupakan data demografi 204 responden untuk kelompok kedua yang digunakan untuk analisis CFA. Pada tabel tersebut, 52,94\% didominasi oleh karyawan dengan jenis kelamin perempuan sementara $47,06 \%$ berjenis kelamin laki-laki. Pada kategori usia responden dengan rentang usia 18-27 tahun memiliki persentase terbesar yaitu 40,2\% yaitu sebanyak 82 orang karyawan. Selanjutnya, pada kategori lama kerja persentase terbesar yaitu $83,82 \%$ berada pada rentang 1-10 tahun sebanyak 171 orang karyawan. Sementara pada kategori pendidikan, karyawan dengan pendidikan SMA/MA memiliki persentase terbanyak sebesar 59,80\%,

Tabel 2.

Responden Kelompok Pertama (EFA)

\begin{tabular}{|c|c|c|c|c|}
\hline No. & Kriteria & Kategori & Total & Presentase \\
\hline \multirow[t]{2}{*}{1} & Jenis Kelamin & Laki-laki & 91 & $45,5 \%$ \\
\hline & & Perempuan & 109 & $54,5 \%$ \\
\hline \multirow[t]{5}{*}{2} & Usia & $16-24$ & 50 & $25 \%$ \\
\hline & & $25-33$ & 60 & $30 \%$ \\
\hline & & $34-42$ & 62 & $31 \%$ \\
\hline & & $43-51$ & 22 & $11 \%$ \\
\hline & & $52-60$ & 6 & $3 \%$ \\
\hline \multirow[t]{5}{*}{3} & Masa Kerja & 1-9 tahun & 141 & $70,5 \%$ \\
\hline & & 10-18 tahun & 33 & $16,5 \%$ \\
\hline & & 19-27 tahun & 20 & $10 \%$ \\
\hline & & 28-36 tahun & 4 & $2 \%$ \\
\hline & & 37-45 tahun & 2 & $1 \%$ \\
\hline \multirow[t]{4}{*}{4} & Pendidikan & $\mathrm{SD} / \mathrm{MI}$ & 14 & $7 \%$ \\
\hline & & SMP/MTS & 27 & $13,50 \%$ \\
\hline & & SMA/MA & 119 & $59,50 \%$ \\
\hline & & D3/S1 & 40 & $20 \%$ \\
\hline \multirow[t]{6}{*}{5} & UMKM & Kresindo & 29 & $14,5 \%$ \\
\hline & & Industri wayang & 20 & $10 \%$ \\
\hline & & Nena Batik & 10 & $5 \%$ \\
\hline & & Logam Jaya & 20 & $10 \%$ \\
\hline & & Tom Silver & 15 & $7,5 \%$ \\
\hline & & Ansor Silver & 106 & $53 \%$ \\
\hline
\end{tabular}


Tabel 3.

Responden Kelompok Dua (CFA)

\begin{tabular}{llccc}
\hline No. & Kriteria & Kategori & Total & Persentase \\
\hline 1 & Jenis Kelamin & Laki-laki & 96 & $47,06 \%$ \\
& & Perempuan & 108 & $52,94 \%$ \\
\hline 2 & Usia & $18-27$ & 82 & $40,2 \%$ \\
& & $28-37$ & 63 & $30,9 \%$ \\
& $38-47$ & 37 & $18,1 \%$ \\
& $48-57$ & 15 & $7,3 \%$ \\
& & $58<$ & 7 & $3,4 \%$ \\
\hline 3 & Masa Kerja & $1-10$ tahun & 171 & $83,82 \%$ \\
& & $11-20$ tahun & 17 & $8,33 \%$ \\
& $21-30$ tahun & 11 & $5,4 \%$ \\
& $31-40$ tahun & 1 & $0,49 \%$ \\
& $40<$ tahun & 4 & $1,96 \%$ \\
\hline 4 & Pendidikan & SD/MI & 21 & $10,3 \%$ \\
& & SMP/MTS & 42 & $20,59 \%$ \\
& SMA/MA & 122 & $59,80 \%$ \\
& & D3/S1 & $9,31 \%$ \\
\hline 5 & UMKM & Rumah Warna & 65 & $31,86 \%$ \\
& & Roy Sentoso & 25 & $12,25 \%$ \\
& Industri wayang & 30 & $14,71 \%$ \\
& Gareng T-Shirt & 55 & $26,96 \%$ \\
& Java Ombus & 15 & $7,35 \%$ \\
& Shinta Imitasi & 5 & $2,45 \%$ \\
& Murni Imitasi & 5 & $2,45 \%$ \\
& Murni Bordir & 4 & $1,96 \%$ \\
\hline
\end{tabular}

Selanjutnya persentase terbanyak kedua ada pada pendidikan SMP/MTS sebesar 20,59\%, di urutan ketiga pada pendidikan SD/MI sebesar 10,3\% dan yang terakhir pendidikan D3/S1 sebesar 9,31\%.

Langkah selanjutnya yang dilakukan setelah diperoleh deskripsi responden penelitian adalah uji prasyarat, yaitu uji normalitas dilakukan untuk mengetahui sebaran data yang ada telah berdistribusi normal atau tidak. Sebuah data dikatakan berdistribusi normal jika memiliki nilai signifikansi lebih besar dari 0,05 ( $>0,05)$, sebaliknya jika nilai signifikansi kecil $(\mathrm{p}<0,05)$ maka dapat dinyatakan bahwa data dalam keadaan tidak normal (Priyatno, 2010). Uji normalitas pertama dilakukan pada data kelompok pertama dengan responden 200 orang. Adapun hasil dari uji normalitas dapat dilihat pada Tabel 4.

Tabel 4.

Test of Normality

\begin{tabular}{lcccccc}
\hline & \multicolumn{3}{c}{ Kolmogorov-Smirnov } & \multicolumn{3}{c}{ Shapiro-Wilk } \\
\cline { 2 - 7 } & Statistic & Df & Sig. & Statistic & Df & Sig. \\
\hline Efektivitas_Tim & .058 & 200 & .099 & .990 & 200 & .173 \\
\hline
\end{tabular}


Berdasarkan Tabel 4 diperoleh nilai signifykansi 0.099. Dari uji normalitas tersebut maka dapat dikatakan bahwa data berdistribusi normal, sehingga peneliti dapat melakukan analisis selanjutnya.

Analisis yang dilakukan pada tahap selanjutnya adalah analisis faktor EFA namun sebelumnya dilakukan uji asumsi dengan melihat nilai Bartlett dan nilai KMO dengan tujuan untuk mengetahui variabel yang digunakan memiliki korelasi dan sampel yang digunakan cukup (Ghozali, 2016). Hasil analisis KMO dan Barlett's test dapat dilihat pada Tabel 5 .

Pada tabel 5 diperoleh nilai Kaiser-MayerOlkin Measure of Sampling Adequacy (KMO) sebesar 0,821. KMO merupakan salah satu uji yang dilakukan untuk melihat metode sampel yang digunakan telah memenuhi syarat atau tidak, sehingga data dapat dilanjutkan untuk dianalisis (Usman \& Sobari, 2013). Menurut Ghozali (2016) analisis faktor dapat dilanjutkan ketika nilai KMO lebih besar dari 0,50, sehingga berdasarkan nilai KMO yang diperoleh maka peneliti dapat melakukan analisis faktor. Selain itu, untuk melihat dapat atau tidaknya dilakukan analisis faktor adalah dengan melihat nilai Barlett's Test of Sphericity untuk melihat korelasi antar variabel. Dari hasil analisis diperoleh signifikansi sebesar 0,000 , yang artinya data ini memenuhi syarat untuk dilakukan analisis selanjutnya karena nilai signifikan yang diperoleh $<0,05$.

Selain itu, peneliti juga melakukan analisis uji measure of sampling adequacy (MSA). Measure of sampling adequacy (MSA) menjadi salah satu uji yang harus terpenuhi untuk dapat melanjutkan analisis faktor. Uji ini dilakukan untuk menguji validitas atribut (Usman \& Sobari, 2013). MSA memiliki nilai yang bervariasi dari $0-1$, jika nilai MSA yang diperoleh $<0,50$ maka analisis faktor tidak dapat dilanjutkan (Ghozali, 2016). Berdasarkan uji yang dilakukan pada 40 item, diperoleh nilai MSA $>0,50$, artinya 40 item telah memenuhi syarat untuk dilakukan analisis.

Pada tahap berikutnya dilakukan analisis ekstraksi faktor. Ekstraksi faktor untuk menentukan jumlah terkecil yang dapat digunakan untuk mewakili keterkaitan antar variable (Pallant, 2010). Seperti yang dikemukakan Widarjono (2010) ekstraksi faktor merupakan metode yang digunakan untuk mereduksi data dari beberapa indikator untuk memperoleh faktor dengan jumlah yang lebih sedikit sehingga dapat menjelaskan hubungan antara indikator yang diobservasi. Metode yang digunakan untuk ekstraksi faktor dalam penelitian ini adalah principal axis factoring.

Pada tabel total variance explained diperoleh nilai yang dapat menunjukkan kontribusi dari variasi suatu faktor yang mampu menjelaskan variasi dari total faktor keseluruhan (Usman \& Sobari, 2013). Nilai Initial Eigenvalues yang lebih besar dari satu ditunjukkan pada faktor 1-12. Dari kedua belas faktor tersebut mampu menjelaskan $54,823 \%$ variasi dari total faktor keseluruhan. Faktor pertama mampu menjelaskan 23,889\% dari total varian. Faktor kedua mampu menjelas-

Tabel 5.

KMO and Bartlett's Test

\begin{tabular}{lrr}
\hline \multicolumn{3}{c}{ KMO and Bartlett's Test } \\
\hline Kaiser-Meyer-Olkin Measure of Sampling Adequacy & .821 \\
Bartlett's Test of & Approx. Chi-Square & $3.520 \mathrm{E} 3$ \\
Sphericity & Df & 780 \\
& sig. & .000 \\
\hline
\end{tabular}


kan 5,591\% dari total varian. Faktor ketiga mampu menjelaskan $4,875 \%$ dari total varian. Faktor keempat mampu menjelaskan 3,711\% dari total varian. Faktor kelima mampu menjelaskan $3,253 \%$ dari total varian. Faktor keenam mampu menjelaskan 2,621\% total varian. Faktor ketujuh mampu menjelaskan 2,502\% total varian. Faktor kedelapan mampu menjelaskan $2,083 \%$ total varian. Faktor kesembilan mampu menjelaskan 1,803\% total varian. Faktor kesepuluh 1,546\% mampu menjelaskan total varian. Faktor kesebelas mampu menjelaskan $1,527 \%$ total varian dan faktor keduabelas mampu menjelaskan $1,422 \%$ total varian. Hanya saja hasil dari total variance explained tersebut belum menjadi nilai patokan hasil dari analisis faktor karena harus dilakukan analisis lebih lanjut. Hasil tersebut dapat dilihat pada Tabel 6 (lihat pada lampiran artikel ini).

Pada tahap selanjutnya, peneliti melakukan rotasi faktor. Teknik rotasi yang digunakan adalah rotasi varimax. Teknik ini menghasilkan sekelompok variabel yang memiliki hubungan yang kuat dalam satu faktor dan tidak memiliki hubungan dengan variabel lainnya (Usman \& Sobari, 2013). Costello dan Osborne (2005) menjelaskan struktur faktor dikatakan telah fit ketika memiliki faktor loading lebih besar dari 0,3, sehingga tidak ada crossloading dan dalam satu faktor memiliki minimal tiga item. Berdasarkan hasil analisis pertama diperoleh beberapa item yang bergabung menjadi satu sehingga peneliti kemudian menaikkan nilai faktor loading $>0,3$, sehingga terbentuklah tiga faktor yang memiliki faktor loading $>0,3$. Analisis tersebut dapat dilihat pada Tabel 7 (lihat pada lampiran artikel ini).

Tabel 7 merupakan hasil akhir setelah peneliti menaikkan faktor loading dengan nilai $>0,3$. Berdasarkan tabel tersebut maka diperoleh tiga faktor. Faktor pertama merupakan gabungan dari aspek sebelumnya, yaitu: pengambilan keputusan, kepercayaan dan penghormatan, peng- akuan dan penghargaan, dan fokus pelanggan. Sementara untuk faktor kedua merupakan gabungan dari aspek pengakuan dan penghormatan, dan dukungan kepemimpinan. Sedangkan untuk faktor ketiga merupakan gabungan dari aspek pengambilan keputusan, dukungan kepemimpinan, dan kepercayaan dan penghormatan. Adanya penggabungan variabel dalam sebuah faktor dikarenakan adanya sekumpulan variabel yang memiliki hubungan kuat dalam satu faktor, dan tidak memiliki korelasi dengan faktor lain (Usman \& Sobari, 2013).

Setelah dilakukan rotasi dan diperoleh tiga faktor, maka peneliti dapat melihat pada tabel total variance explained. Nilai yang diperoleh dari tabel total variance explained menunjukkan kontribusi variasi dari suatu faktor yang mampu menjelaskan variasi secara total (Usman \& Sobari, 2013). Berdasarkan kolom extraction sums of squared loadings dapat dilihat bahwa faktor satu memiliki nilai total variasi $23,395 \%$, faktor kedua menjelaskan 5,058\% variasi, dan faktor ketiga $4,362 \%$ variasi. Total variance explained dari hasil analisis akhir dapat dilihat pada Tabel 8 (lihat pada lampiran artikel ini).

Pada analisis selanjutnya peneliti melakukan confirmatory factor analysis atau CFA. Hasil analisis awal yang dilakukan pada model diperoleh dari hasil analisis EFA yaitu tiga faktor dengan 18 item. Peneliti melakukan analisis convergent validity yang merupakan analisis untuk mengetahui item-item dari suatu konstruk laten telah berkumpul dengan proporsi varian yang tinggi (Ghozali, 2017), melihat nilai faktor loading yang signifikan dengan nilai standardized loading estimate $\geq 0,50$. Hasil analisis menunjukkan terdapat dua item yang memiliki nilai estimate $<0,50$ yaitu pada item 9 dan 10 pada aspek 1, sehingga item tersebut digugurkan. Hasil analisis dapat dilihat pada Tabel 9. 
Tabel 9.

Standardized Regression Weights

\begin{tabular}{|c|c|}
\hline & Estimate \\
\hline ET1.10 $\leftarrow$ Aspek 1 & ,361 \\
\hline ET1.9 $\leftarrow$ Aspek 1 & ,316 \\
\hline ET1.8 $\leftarrow$ Aspek 1 & 855 \\
\hline ET1.7 $\leftarrow$ Aspek1 & ,724 \\
\hline ET1.6 $\leftarrow$ Aspek1 & 801 \\
\hline ET1.5 $\leftarrow$ Aspek1 & ,745 \\
\hline ET1.4 $\leftarrow$ Aspek1 & 829 \\
\hline ET1.3 $\leftarrow$ Aspek1 & 841 \\
\hline ET1.2 $\leftarrow$ Aspek1 & 705 \\
\hline ET1.1 $\leftarrow$ Aspek1 & 621 \\
\hline ET2.5 $\leftarrow$ Aspek 2 & 779 \\
\hline ET2.4 $\leftarrow$ Aspek2 & 788 \\
\hline ET2.3 $\leftarrow$ Aspek2 & ,665 \\
\hline ET2.2 $\leftarrow$ Aspek 2 & ,786 \\
\hline ET2.1 $\leftarrow$ Aspek2 & 754 \\
\hline ET3.3 $\leftarrow$ Aspek3 & ,768 \\
\hline ET3.2 $\leftarrow$ Aspek3 & ,740 \\
\hline ET3.1 $\leftarrow$ Aspek3 & 673 \\
\hline
\end{tabular}

Berikutnya peneliti melakukan analisis pada enam belas item yang valid untuk melihat model fit melalui hasil Chi-Square, CMIN/DF, CFI, Goodnes of fit index (GFI), Root Mean Square Error of Approximation (RMSEA). Hasil tersebut dapat dilihat pada Tabel 10.

Tabel 10 menunjukkan nilai probabilitas $<0,05$ sehingga peneliti melakukan modifikasi model untuk menurunkan nilai chi-square dan menaikkan nilai probabilitas. Modifikasi dilakukan dengan melihat nilai modification indices. Ghozali (2017) mengemukakan ketika modifycation indices dilakukan dengan mengkovariankan antar error atau residual harus berlandaskan teoretis atau logika. Modifikasi dilakukan dengan mengkovariankan antar error yaitu pada e10 dengan e15, e2 dengan e12, e5 dengan e6, e7 dengan e11, e11 dengan e10, e7 dengan e16, e4 dengan $\mathrm{e} 16$.

Kovarian dilakukan berdasarkan adanya kemiripan pada item, seperti pada e10 dengan e15 yang ditunjukkan dengan item nomor 13 dan 15, item menunjukkan bagaimana peran pemimpin dalam tim. Sementara pada e2 dan e12 yang ditunjukkan pada nomor 7 dan 10, bunyi item tersebut menunjukkan adanya hubungan terkait dengan proses pemberian penghargaan dan pengakuan dalam tim kerja.

Tabel 10.

Hasil Analisis CFA

\begin{tabular}{lccc}
\hline & $\begin{array}{c}\text { Control of } \\
\text { Value }\end{array}$ & Hasil Analisis & Kategori \\
\hline Chi-Square & $\mathrm{p}>0,05$ & 0,000 & Marginal \\
CMIN/DF & $\leq 2,0$ & 1,740 & Fit \\
GFI & $\geq 0,90$ & 0,901 & Fit \\
RMSEA & $\leq 0,08$ & 0,060 & Fit \\
\hline
\end{tabular}


Tabel 11.

Hasil Analisis Konfirmatori (CFA) setelah Dimodifikasi

\begin{tabular}{lccc}
\hline & Control of Value & Hasil Analisis & Kategori \\
\hline Chi-Square & $\mathrm{p}>0,05$ & 0,057 & Fit \\
CMIN/DF & $\leq 2,0$ & 1,240 & Fit \\
GFI & $\geq 0,90$ & 0,932 & Fit \\
RMSEA & $\leq 0,08$ & 0,034 & Fit \\
\hline
\end{tabular}

Pada kovarian e5 dan e6 yang ditunjukkan dengan nomor 3 dan 4, item tersebut merupakan item yang bergabung menjadi satu dalam faktor pengambilan keputusan. Selanjutnya kovarian yang dilakukan pada e7 dengan e11 yang ditunjukkan dengan nomor 2 dan 11, bunyi item ke dua item tersebut memiliki hubungan terkait dengan keterlibatan anggota tim dalam proses penyelesaian masalah.

Berikutnya kovarian yang dilakukan pada e11 dengan e10, ditunjukkan dengan nomor 11 dan 12. Kedua item tersebut merupakan item dari dukungan kepemimpinan. Kovarian yang dilakukan pada error e7 dengan e16 yang ditunjukkan dengan nomor 2 dan 14, kedua item tersebut merupakan item pembangun dari aspek pengambilan keputusan pada teori awal yang dikemukakan oleh Cantu (2007). Berikutnya kovarian e4 dengan e16 yang ditunjukkan dengan nomor 5 dan 14. Hasil kovarian yang dilakukan meningkatkan nilai probabilitas yang dapat dilihat pada Tabel 11.

Berdasarkan hasil analisis dengan mengkovariankan antar error yang telah dilakukan, diperoleh model fit melalui nilai Chi-Square, CMIN/DF, Goodnes of fit index (GFI), Root Mean Square Error of Approximation (RMSEA).

Berdasarkan Tabel 11 diperoleh hasil yang fit. Menurut Solimun (2002) berdasarkan prinsip parsimony jika terdapat salah satu atau dua kriteria yang fit maka model tersebut dinyatakan telah fit sehingga dapat disimpulkan secara umum konstruk ini fit untuk digunakan dalam mengukur efektivitas tim di UMKM. Model yang diperoleh dari hasil analisis CFA dapat dilihat pada Gambar 1.

Analisis berikutnya dilakukan untuk melihat reliabilitas. Alat ukur dikatakan reliabel jika nilai component reliability $(\mathrm{CR}) \geq 0,7$. Dari hasil perhitungan uji reliabilitas diperoleh nilai CR pada faktor satu 0,919 , faktor dua sebesar 0,871, dan faktor tiga sebesar 0,760. Menurut Ghozali (2017) nilai construct reliability $\geq 0,70$ menunjukkan reliabilitas yang baik, sehingga ketiga aspek pada penelitian ini memiliki reliabilitas yang baik, karena memiliki nilai $\mathrm{CR}>0,7$.

\section{Diskusi}

Penelitian sebelumnya tentang efektivitas tim telah dilakukan van Roosmalen (2012) untuk mengembangkan kuesioner berdasarkan pengalaman subjektif dari kerja sama tim dan menggunakan teori klasifikasi efektivitas tim. Penelitian tersebut berfokus pada proses dan hasil dalam efektivitas tim dan hanya menggunakan exploratory factor analysis (EFA) dengan rotasi oblimin. Rotasi tersebut dilakukan dengan tujuan untuk memperoleh faktor yang sesuai dengan teori. Sementara penelitian ini bertujuan untuk mengetahui validitas konstruk dari alat ukur efektivitas tim di UMKM. Sebelum dilakukannya analisis faktor peneliti terlebih dahulu melakukan uji asumsi, yaitu uji normalitas.

Sebelum dilakukannya analisis faktor, peneliti terlebih dahulu melakukan tiga uji prasyarat untuk melakukan analisis faktor, yaitu uji Barlett, Uji Kaiser Mayer Olkin (KMO), dan Uji Measure of Sampling Adequacy (MSA). 


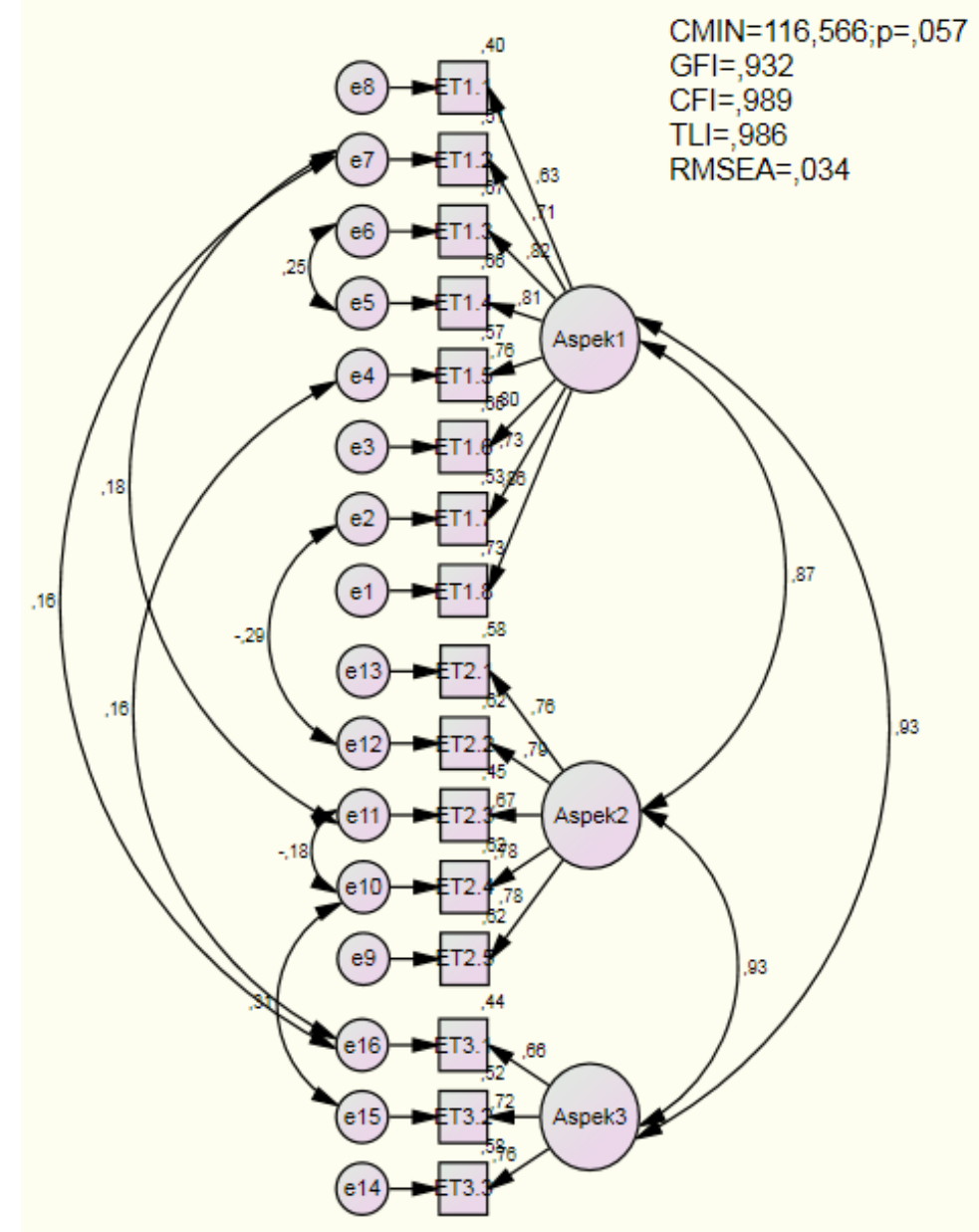

Gambar 1. Analisis Faktor Skala Efektivitas Tim setelah CFA

Tahap analisis selanjutnya adalah dilakukannya rotasi faktor. Teknik rotasi yang digunakan adalah rotasi varimax yaitu metode yang digunakan untuk memperoleh sekumpulan variabel yang berkorelasi kuat dalam satu faktor dan tidak mempunyai hubungan dengan faktor lain (Usman \& Sobari, 2013). Dari hasil tersebut terbentuk tiga faktor, dengan 18 item.

Alat ukur efektivitas tim dalam penelitian ini memiliki enam aspek pembangun yaitu: kerja sama tim, pengambilan keputusan, dukungan kepemimpinan, kepercayaan dan penghormatan, pengakuan dan penghargaan, dan fokus pelang- gan. Sebelum dilakukannya analisis dari enam aspek tersebut, skala memiliki 40 item. Peneliti melakukan analisis faktor terhadap enam aspek pembangun efektivitas tim tersebut, sehingga diperoleh jumlah faktor yang berbeda dari aspek sebelumnya. Efektivitas tim di UMKM memunculkan tiga faktor. Faktor pertama terdiri dari gabungan antara aspek pengambilan keputusan, kepercayaan dan penghormatan, pengakuan dan penghargaan, dan fokus pelanggan. Sementara untuk faktor dua terbentuk dari gabungan aspek pengakuan dan penghormatan, dan dukungan kepemimpinan. Pada faktor tiga 
terbentuk dari aspek pengambilan keputusan, dukungan kepemimpinan, kepercayaan dan penghormatan.

Faktor pertama yang merupakan gabungan dari faktor pengambilan keputusan, kepercayaan dan penghormatan, pengakuan dan penghargaan, fokus pelanggan memiliki 10 item. Tiga item diwakili dari aspek pengambilan keputusan, tiga item diwakili dari aspek kepercayaan dan penghormatan, dua item dari aspek pengakuan dan penghargaan, dan dua item dari aspek fokus pelanggan. Item-item yang bergabung dalam faktor satu memiliki kemiripan bunyi item. Kebanyakan konten dari item tersebut tentang proses diskusi, bertukar pendapat, dan penyelesaian masalah. Oleh sebab itu peneliti memilih nama pengambilan keputusan untuk faktor satu walaupun di dalamnya terdapat item yang memiliki konten pengakuan dan penghargaan tetapi item yang mendominasi adalah item yang berbunyi tentang proses pengambilan keputusan. Pengambilan keputusan merupakan indikator penting karena merupakan suatu proses yang dilakukan untuk membuat atau memutuskan suatu pilihan atau menentukan keputusan dari beberapa alternatif (Bhudianto, 2015). Pengambilan keputusan dalam kelompok akan menghasilkan informasi dan pengetahuan yang lebih lengkap. Keputusan yang diambil diperoleh dari proses diskusi dengan adanya proses saling bertukar pikiran, sehingga menghasilkan keragaman pandangan yang lebih luas. Proses pengambilan keputusan dalam kelompok dilakukan dengan adanya interaksi tatap muka secara langsung dengan berkomunikasi baik verbal ataupun non verbal (Robbins \& Judge, 2015).

Faktor kedua terbentuk dari gabungan aspek pengakuan dan penghormatan, dan dukungan kepemimpinan. Pada faktor ini item pembentuk didominasi dengan aspek dukungan kepemimpinan yaitu tiga item dari aspek dukungan kepemimpinan. Bunyi item menunjukkan peran pemimpin dalam sebuah tim dan adanya penghargaan yang diberikan kepada setiap anggota tim. Kepemimpinan merupakan sebuah proses pada saat individu mampu mempengaruhi orang lain atau kelompok dalam mencapai sebuah tujuan (Rini, 2006). Pemimpin akan memberikan dukungan dan arahan untuk mencapai tujuan bersama (Northouse, 2013). Dukungan kepemimpinan sangat penting untuk meraih kesuksesan di dalam tim karena dukungan kepemimpinan adalah sejauh mana seorang pemimpin mampu berfungsi sebagai pemandu yang efektif dan memberikan dukungan serta dorongan dalam sebuah tim kerjanya (Cantu, 2007). Pada faktor ini peneliti memilih dukungan kepemimpinan sebagai nama untuk faktor kedua berdasarkan variabel yang terbentuk pada faktor tersebut.

Faktor ketiga terdiri dari tiga item yang terbentuk dari aspek pengambilan keputusan, dukungan kepemimpinan, serta kepercayaan dan penghormatan. Pada faktor tiga peneliti memilih trust atau kepercayaan sebagai nama untuk faktor tersebut. Nama trust atau kepercayaan sudah ada pada aspek sebelumnya, hanya saja item yang terbentuk berasal dari aspek yang berbeda. Kepercayaan merupakan derajat kepercayaan dalam sebuah tim (Cantu, 2007). Tim yang efektif adalah tim yang saling mempercayai satu sama lain. Adanya kepercayaan antar anggota tim dapat menumbuhkan kerja sama, menurunkan kebutuhan untuk memonitor perilaku anggota tim, dan menimbulkan perasaan untuk tidak saling mengambil keuntungan dari anggota lainnya (Robbins \& Judge, 2015). Trust atau kepercayaan merupakan pondasi yang memungkinkan seseorang untuk bekerjasama. Hal utama yang membangun kepercayaan adalah pengetahuan pribadi, interaksi tatap muka, empati, rasa hormat dan pendengar yang tulus 
(Hakanen, Häkkinen, \& Soudunsaari, 2015). Larson dan La Fasto (dalam Hakanen et al., 2015) menambahkan bahwa kepercayaan memiliki empat unsur utama yaitu kejujuran, keterbukaan, konsistensi, dan rasa hormat.

Selain itu, dari hasil analisis pada 40 item, diperoleh 18 item yang valid. Kondisi ini sebenarnya sudah diantisipasi karena dalam penelitian ini dilakukan pilot study. Para responden diminta untuk melakukan klarifikasi pemahaman dan pemaknaan terhadap item-item, apakah dapat dipahami sesuai harapan peneliti atau perlu ditulis ulang sehingga responden memiliki pemaknaan seperti yang peneliti inginkan di setiap item. Selain itu, antisipasi juga dilakukan dengan penulisan item dilakukan peneliti sehingga sesuai dengan budaya di Indonesia. Pengurangan jumlah item yang besar ini ini dapat disebabkan item-item memiliki banyak kesamaan dalam hal kata maupun makna, sehingga menyebabkan variasi item cenderung rendah. Oleh karena itu, keterbatasan dari penelitian ini terkait jumlah item yang tereduksi perlu dikoreksi oleh penelitian selanjutnya.

Van Roosmalen (2012) mengembangkan kuesioner efektivitas tim berdasarkan pengalaman subjektif dari kerja sama tim dan klasifikasi efektivitas tim. Dalam penelitian tersebut, van Roosmalen (2012) menggunakan exploratory factor analysis (EFA) saja. Berbeda dengan penelitian tersebut, penelitian ini melakukan analisis EFA dan CFA. Dari hasil analisis EFA diperoleh 18 item dari tiga faktor. Skala yang valid dari analisis EFA kemudian disebar kembali kepada 204 responden yang berbeda untuk digunakan dalam CFA. Dari hasil uji validitas awal pada 18 item diperoleh dua faktor yang memiliki nilai factor loading di bawah 0,5. Dalam uji validitas konstruk terdapat syarat yang harus terpenuhi yaitu memiliki factor loading yang signifikan dengan standardized loading estimate $\geq 0,50$ (Ghozali, 2017), sehingga berdasarkan acuan tersebut maka dua faktor yang memiliki nilai estimate $<0,5$ tersebut tidak diikutsertakan dalam analisis selanjutnya. Seperti dikemukakan Ghozali (2017), item dalam suatu konstruk laten harus bergabung dengan proporsi varian yang tinggi.

Analisis selanjutnya dilakukan pada 16 item yang valid diperoleh nilai chi-square 175,702 dengan probabilitas 0,000. Menurut Widarjono (2010) model analisis konfirmatori dikatakan layak ketika hipotesis nol diterima, yaitu ketika nilai $p$-value lebih besar dari 0,05 sehingga dari pendapat ahli tersebut maka perlu dilakukan respesifikasi model atau modifikasi model. Respesifikasi model merupakan langkah yang dilakukan ketika dilakukan uji kelayakan model dengan menggunakan salah satu uji kelayakan namun hasil yang diperoleh adalah model yang tidak layak (Widarjono, 2010). Pada penelitian ini, modifikasi dilakukan dengan jenis covariance, yaitu modifikasi model yang dilakukan dengan mencari hubungan atau korelasi antara residual. Modifikasi dilakukan dengan melihat nilai modification indices yaitu dari kolom per change yang memiliki nilai paling besar, yang digunakan untuk menurunkan nilai chi-Square, hal ini dilakukan agar secara statistik dapat menerima hipotesis nol sehingga model dapat dikatakan layak untuk digunakan. Selain itu, modification indices dilakukan dengan mengkovariankan antar error atau residual harus berlandaskan teoritis atau logika.

Modifikasi yang telah dilakukan memperoleh nilai CMIN sebesar 116,566 dengan probabilitas sebesar 0,057 atau lebih besar dari 0,05. Sebuah model dikatakan fit ketika memiliki nilai chisquare $\mathrm{p}>0,05$ atau $\mathrm{p}>0,10$ (Hulland, Chow, \& Lam, 1996). Berdasarkan hal tersebut, maka dapat 
dikatakan model telah layak. Untuk uji kelayakan model juga dapat dilihat dari nilai CMIN/DF, GFI, dan RMSEA. Dari hasil analisis diperoleh nilai CMIN/DF sebesar 1,240. Standar nilai yang diharapkan CMIN/DF $\leq 2,0$ (Waluyo, 2016), sehingga berdasarkan standar tersebut maka nilai telah memenuhi standar yang diharapkan. Nilai GFI yang diperoleh dari hasil analisis sebesar 0,932. RMSEA merupakan ukuran untuk mencoba memperbaiki kecenderungan statistic chi-square yang menolak model dengan jumlah sampel besar. RMSEA yang diperoleh dari hasil analisis sebesar 0,034 , sehingga memiliki nilai yang $<0,08$. Nilai RMSEA dikatakan layak ketika memiliki nilai < 0,08. Berdasarkan hasil analisis CFA telah memenuhi uji kelayakan sehingga secara umum model telah fit untuk digunakan dalam mengukur efektivitas tim di UMKM.

Dari hasil perhitungan uji reliabilitas diperoleh nilai Construct Reliability atau CR pada aspek satu 0,919, faktor dua sebesar 0,871, dan faktor 3 sebesar 0,760. Menurut Ghozali (2017) nilai construct reliability $\geq 0,70$ menunjukkan reliabilitas yang baik, sehingga dengan demikian ketiga aspek pada penelitian ini memiliki reliabilitas yang baik, karena memiliki nilai $\mathrm{CR}>0,7$.

Berdasarkan uraian sebelumnya bahwa dari hasil analisis EFA yang telah dilakukan pada skala efektivitas tim diperoleh hasil yang menunjukkan adanya perubahan aspek yang semula memiliki enam aspek kemudian berubah menjadi tiga faktor pembangun efektivitas tim di UMKM. Dari hasil analisis tersebut juga menggugurkan 22 item sehingga dari 40 item menjadi 18 item. Sementara dari hasil analisis konfirmatori atau
CFA yang dilakukan masih ada dua item yang tidak valid, sehingga hasil akhir diperoleh 16 item yang valid dari tiga faktor pembangun efektivitas tim di UMKM.

\section{Simpulan}

Berdasarkan hasil penelitian dengan menggunakan analisis EFA dan CFA diperoleh hasil, yaitu: pertama dari hasil analisis EFA yang telah dilakukan, terbentuk tiga faktor pembangun efektivitas tim di UMKM yaitu pengambilan keputusan, dukungan kepemimpinan, dan kepercayaan. Dari hasil analisis CFA, diperoleh model fit dari nilai CMIN, CMIN/DF, GFI, dan RMSEA, dan uji reliabilitas diperoleh nilai yang menunjukkan alat ukur sudah valid dan reliabel untuk mengukur efektivitas tim di UMKM.

\section{Saran}

Bagi perusahaan skala efektivitas tim yang dihasilkan dari penelitian ini dapat digunakan untuk mengukur efektivitas tim yang ada di UMKM dan hasil dari pengukuran efektivitas tim dapat dijadikan sebagai salah satu dasar untuk pengembangan tim di UMKM. Sementara, bagi peneliti selanjutnya diharapkan dapat mengembangkan jumlah item dan aspek pembangun efektivitas tim berdasarkan budaya dan kondisi yang ada di UMKM yang menjadi tempat penelitian. Selain itu juga disarankan dapat memperluas populasi dengan jenis UMKM yang beragam, sehingga nantinya dapat memperoleh alat ukur yang tidak hanya mengukur efektivitas tim di industri kreatif tetapi juga dapat digunakan pada jenis UMKM yang berbeda.[

\section{Daftar Pustaka}

Azwar, S. (2013). Penyusunan skala psikologi. Yogyakarta: Pustaka Pelajar.

Bhudianto, W. (2015). Kepemimpinan dalam pengambilan keputusan. Transformasi, 27(1), 18-23. Retrieved from https://ejurnal.unisri.ac.id/index.php/Transformasi/article/view/910/762 
Buzaglo, G., \& Wheelan, S. A. (1999). Facilitating work team effectiveness: Case studies from Central America. Small Group Research, 30(1), 108-129. https://doi.org/10.1177/ 104649649903000106

Cantu, C. J. (2007). Evaluating team effectiveness: Examination of the TEAM Assessment Tool. North Texas: University of North Texas. Retrieved from https://digitallibrary.unt.edu/ ark:/67531/metadc3990/

Costello, A. B., \& Osborne, J. W. (2005). Best practices in exploratory factor analysis: Four recommendations for getting the most from your analysis, 10(7), 1-10. Retrieved from https://www.semanticscholar.org/paper/Best-Practices-in-Exploratory-Factor-Analysis\%3A-for-Costello-Osborne/7ce6c453c20dae3bff4d792fbd1dcfd252fc7fc2

Cummings, T. G., \& Worley, C. G. (2008). Organization development \& change. Mason, Ohio, USA: SouthWestern - Cengage Learning.

Ghozali, I. (2016). Analisis multivariate program IBM SPSS 19. Semarang: Badan Penerbit Universitas Diponegoro.

Ghozali, I. (2017). Model persamaan struktural konsep dan aplikasi dengan Program AMOS 24 (update Bayesian SEM). Semarang: Badan Penerbit Universitas Diponegoro.

Hakanen, M., Häkkinen, M., \& Soudunsaari, A. (2015). Trust in building high-performing teams - conceptual approach. EJBO: Electronic Journal of Business Ethics and Organization Studies, 20(2), 343-353. https://doi.org/10.1897/08-563.1

Hexmoor, H., \& Beavers, G. (2002). Measuring team effectiveness. In Proceedings of 20th IASTED International Multiconference: (Vol. 74, pp. 338-343). Innsbruck, Austria: IASTED. https://doi.org/10.1177/109634808901300334

Mohanty, A., \& Mohanty, S. (2018). The impact of communication and group dynamics on teamwork effectiveness: The case of service sector organisations. Academy of Strategic Management Journal, 17(4), 1-14.

Northouse, P. G. (2013). Kepemimpinan: Teori dan praktik (6th ed.). Jakarta: Indeks Gramedia.

Pallant, J. (2010). SPSS survival manual: A step by step guide to data analysis using the SPSS program. Australia: Allen \& Unwin Book Publishers.

Pratiwi, W. K., \& Nugrohoseno, D. (2014). Pengaruh kepribadian terhadap kerjasama tim dan dampaknya terhadap kinerja karyawan. Bisma (Bisnis dan Manajemen), 7(1), 63-72. https://doi.org/10.26740/bisma.v7n1.p63-72

Priyatno, D. (2010). Paham analisa statistik data dengan SPSS Plus: Tata cara dan tips menyusun skripsi dalam waktu singkat. Jakarta: Elex Media Komputindo.

Rini, W. A. (2006). Kepemimpinan yang membangun tim. Modernisasi, 2(2), 66-75.

Robbins, S. P., \& Judge, T. A. (2015). Perilaku organisasi. (R. Saraswati, Terj.) (16th ed.). Jakarta: Salemba Empat.

Solimun, M. S. (2002). Structural Equation Modelling (SEM) Lisrel dan Amos. Malang: Fakultas MIPA Universitas Brawijaya.

Sudirman, F. (2013). Pemberian motivasi dalam upaya meningkatkan efektifitas kerja pegawai pada Kantor Kecamatan Kuaro Kabupaten Paser. E-Journal Ilmu Pemerintahan, 1(1), 46-56. Retrieved from http://ejournal.ip.fisip-unmul.ac.id/site/wp-content/uploads/2013/02/ journal dampak eksos \%2802-12-13-01-34-45\%29.pdf 
Usman, H., \& Sobari, N. (2013). Aplikasi teknik multivariate untuk riset pemasaran. Jakarta: Raja Grafindo Persada.

van Roosmalen, T. M. (2012). The development of a questionnaire on the subjective experience of teamwork, based on Salas, Sims and Burke's "the big five of teamwork" and Hackman's understanding of team effectiveness. Trondheim: Norges Teknisk Naturvitenskapelige Universitet. Retrieved from https://brage.bibsys.no/xmlui/handle/11250/270920

Waluyo, M. (2016). Mudah cepat tepat penggunaan tools Amos dalam aplikasi (SEM). Surabaya: UPN Veteran Jawa Timur.

Widarjono, A. (2010). Analisis statistika multivariat terapan. Yogyakarta: UPP STIM YKPN.

Widodo, P. B. (2006). Reliabilitas dan validitas konstruk skala konsep diri untuk mahasiswa Indonesia. Jurnal Psikologi, 3(1), 1-9. https://doi.org/10.14710/JPU.3.1.1 - 9 
Pengembangan dan Validasi Instrumen Pengukuran Efektivitas Tim ....

\section{Lampiran}

Tabel 6.

Total Variance Explained

\begin{tabular}{|c|c|c|c|c|c|c|c|c|c|}
\hline \multirow{2}{*}{ Factor } & \multicolumn{3}{|c|}{ Initial Eigenvalues } & \multicolumn{3}{|c|}{ Extraction Sums of Squared Loadings } & \multicolumn{3}{|c|}{ Rotation Sums of Squared Loadings } \\
\hline & Total & $\%$ of Variance & Cumulative \% & Total & $\%$ of Variance & Cumulative \% & Total & $\%$ of Variance & Cumulative \% \\
\hline 1 & 9.993 & 24.984 & 24.984 & 9.556 & 23.889 & 23.889 & 3.181 & 7.953 & 7.953 \\
\hline 2 & 2.671 & 6.678 & 31.661 & 2.236 & 5.591 & 29.480 & 2.535 & 6.337 & 14.290 \\
\hline 3 & 2.352 & 5.880 & 37.541 & 1.950 & 4.875 & 34.355 & 2.405 & 6.013 & 20.303 \\
\hline 4 & 1.913 & 4.782 & 42.323 & 1.484 & 3.711 & 38.066 & 2.114 & 5.286 & 25.589 \\
\hline 5 & 1.730 & 4.326 & 46.649 & 1.301 & 3.253 & 41.320 & 1.963 & 4.909 & 30.498 \\
\hline 6 & 1.514 & 3.785 & 50.434 & 1.048 & 2.621 & 43.941 & 1.766 & 4.414 & 34.912 \\
\hline 7 & 1.448 & 3.619 & 54.053 & 1.001 & 2.502 & 46.442 & 1.744 & 4.359 & 39.271 \\
\hline 8 & 1.279 & 3.198 & 57.251 & .833 & 2.083 & 48.525 & 1.497 & 3.741 & 43.012 \\
\hline 9 & 1.176 & 2.941 & 60.192 & .721 & 1.803 & 50.328 & 1.367 & 3.418 & 46.430 \\
\hline 10 & 1.101 & 2.751 & 62.943 & .618 & 1.546 & 51.874 & 1.248 & 3.121 & 49.550 \\
\hline 11 & 1.049 & 2.624 & 65.567 & .611 & 1.527 & 53.400 & 1.143 & 2.857 & 52.407 \\
\hline 12 & 1.034 & 2.586 & 68.152 & .569 & 1.422 & 54.823 & .966 & 2.416 & 54.823 \\
\hline 13 & .939 & 2.347 & 70.499 & & & & & & \\
\hline 14 & .871 & 2.178 & 72.677 & & & & & & \\
\hline 15 & .846 & 2.115 & 74.792 & & & & & & \\
\hline 16 & .778 & 1.945 & 76.737 & & & & & & \\
\hline 17 & .701 & 1.753 & 78.491 & & & & & & \\
\hline 18 & .670 & 1.674 & 80.165 & & & & & & \\
\hline 19 & .647 & 1.617 & 81.782 & & & & & & \\
\hline 20 & .569 & 1.424 & 83.206 & & & & & & \\
\hline 21 & .562 & 1.406 & 84.611 & & & & & & \\
\hline 22 & .533 & 1.333 & 85.944 & & & & & & \\
\hline 23 & .492 & 1.230 & 87.174 & & & & & & \\
\hline 24 & .465 & 1.162 & 88.336 & & & & & & \\
\hline 25 & .450 & 1.124 & 89.460 & & & & & & \\
\hline 26 & .438 & 1.095 & 90.555 & & & & & & \\
\hline 27 & .400 & 1.000 & 91.556 & & & & & & \\
\hline 28 & .393 & .983 & 92.538 & & & & & & \\
\hline 29 & .368 & .921 & 93.460 & & & & & & \\
\hline 30 & .353 & .883 & 94.342 & & & & & & \\
\hline 31 & .326 & .814 & 95.156 & & & & & & \\
\hline 32 & .303 & .758 & 95.915 & & & & & & \\
\hline 33 & .265 & .664 & 96.578 & & & & & & \\
\hline 34 & .255 & .638 & 97.216 & & & & & & \\
\hline 35 & .241 & .602 & 97.819 & & & & & & \\
\hline 36 & .194 & .486 & 98.305 & & & & & & \\
\hline 37 & .193 & .482 & 98.787 & & & & & & \\
\hline 38 & .175 & .438 & 99.224 & & & & & & \\
\hline 39 & .156 & .389 & 99.614 & & & & & & \\
\hline 40 & .155 & .386 & 100.000 & & & & & & \\
\hline xtraction & thod: & Principal Axis Fc & actoring. & & & & & & \\
\hline
\end{tabular}


Tabel 7.

Rotated Factor Matrix

\begin{tabular}{|c|c|c|c|c|}
\hline & \multirow{2}{*}{ Rotated Factor Matrix ${ }^{a}$} & \multicolumn{3}{|c|}{ Factor } \\
\hline & & 1 & 2 & 3 \\
\hline 1 & $\begin{array}{l}\text { Anggota tim mengerjakan pekerjaan sesuai dengan permintaan } \\
\text { pelanggan. }\end{array}$ & .594 & & \\
\hline 2 & Anggota tim berdiskusi saat memecahkan suatu persoalan. & .584 & & \\
\hline 3 & Anggota tim memiliki kebebasan untuk menyampaikan masukan. & .545 & & \\
\hline 4 & Terdapat anggota tim yang tidak bersikap jujur dalam bekerja. & .539 & & \\
\hline 5 & Tidak ada bonus yang diberikan ketika tim bekerja melebihi target. & .538 & & \\
\hline 6 & $\begin{array}{l}\text { Setiap anggota tim memastikan kembali apakah pesanan sudah } \\
\text { sesuai dengan keinginan pelanggan. }\end{array}$ & .536 & & \\
\hline 7 & $\begin{array}{l}\text { Bonus atau pujian yang diterima dapat meningkatkan kesetiaan } \\
\text { anggota tim untuk tetap bekerja di perusahaan atau tempat kerja. }\end{array}$ & .527 & & \\
\hline 8 & $\begin{array}{l}\text { Setiap anggota tim tidak diberikan kesempatan untuk } \\
\text { menyampaikan pendapatnya. }\end{array}$ & .515 & & \\
\hline 9 & $\begin{array}{l}\text { Tidak semua anggota tim menyampaikan pendapatnya dalam } \\
\text { proses pengambilan keputusan. }\end{array}$ & .514 & & \\
\hline 10 & $\begin{array}{l}\text { Tidak semua anggota tim bekerja sama untuk menyelesaikan } \\
\text { permasalahan. }\end{array}$ & .511 & & \\
\hline 11 & $\begin{array}{l}\text { Pemimpin mencari modal usaha untuk berlangsungnya proses } \\
\text { kerja. }\end{array}$ & & .604 & \\
\hline 12 & Pemimpin menyediakan kebutuhan anggota tim dalam bekerja. & & .587 & \\
\hline 13 & $\begin{array}{l}\text { Anggota tim mendapatkan pujian ketika menghasilkan kinerja } \\
\text { terbaik. }\end{array}$ & & .521 & \\
\hline 14 & $\begin{array}{l}\text { Bonus dan pujian yang diberikan dapat meningkatkan kepuasan } \\
\text { anggota tim. }\end{array}$ & & .517 & \\
\hline 15 & $\begin{array}{l}\text { Pemimpin tidak melibatkan anggota tim dalam pengambilan } \\
\text { keputusan. }\end{array}$ & & .507 & \\
\hline $\begin{array}{l}1 \\
6\end{array}$ & $\begin{array}{l}\text { Keputusan yang diambil dalam tim tidak melalui hasil diskusi } \\
\text { bersama }\end{array}$ & & & .707 \\
\hline 17 & $\begin{array}{l}\text { Pemimpin tidak memberikan dukungan untuk meningkatkan kinerja } \\
\text { anggota tim. }\end{array}$ & & & .600 \\
\hline 18 & $\begin{array}{l}\text { Anggota tim menyampaikan pendapatnya baik itu setuju atau tidak } \\
\text { setuju dengan sopan. }\end{array}$ & & & .547 \\
\hline
\end{tabular}


Pengembangan dan Validasi Instrumen Pengukuran Efektivitas Tim ....

Tabel 8.

Total Variance Explained

\begin{tabular}{|c|c|c|c|c|c|c|c|c|c|}
\hline \multirow{2}{*}{ Factor } & \multicolumn{3}{|c|}{ Initial Eigenvalues } & \multicolumn{3}{|c|}{ Extraction Sums of Squared Loadings } & \multicolumn{3}{|c|}{ Rotation Sums of Squared Loadings } \\
\hline & Total & $\%$ of Variance & Cumulative \% & Total & $\%$ of Variance & Cumulative \% & Total & $\%$ of Variance & Cumulative \% \\
\hline 1 & 9.993 & 24.984 & 24.984 & 9.358 & 23.395 & 23.395 & 5.601 & 14.002 & 14.002 \\
\hline 2 & 2.671 & 6.678 & 31.661 & 2.023 & 5.058 & 28.453 & 3.816 & 9.539 & 23.541 \\
\hline 3 & 2.352 & 5.880 & 37.541 & 1.745 & 4.362 & 32.815 & 3.710 & 9.275 & 32.815 \\
\hline 4 & 1.913 & 4.782 & 42.323 & & & & & & \\
\hline 5 & 1.730 & 4.326 & 46.649 & & & & & & \\
\hline 6 & 1.514 & 3.785 & 50.434 & & & & & & \\
\hline 7 & 1.448 & 3.619 & 54.053 & & & & & & \\
\hline 8 & 1.279 & 3.198 & 57.251 & & & & & & \\
\hline 9 & 1.176 & 2.941 & 60.192 & & & & & & \\
\hline 10 & 1.101 & 2.751 & 62.943 & & & & & & \\
\hline 11 & 1.049 & 2.624 & 65.567 & & & & & & \\
\hline 12 & 1.034 & 2.586 & 68.152 & & & & & & \\
\hline 13 & .939 & 2.347 & 70.499 & & & & & & \\
\hline 14 & .871 & 2.178 & 72.677 & & & & & & \\
\hline 15 & .846 & 2.115 & 74.792 & & & & & & \\
\hline 16 & .778 & 1.945 & 76.737 & & & & & & \\
\hline 17 & .701 & 1.753 & 78.491 & & & & & & \\
\hline 18 & .670 & 1.674 & 80.165 & & & & & & \\
\hline 19 & .647 & 1.617 & 81.782 & & & & & & \\
\hline 20 & .569 & 1.424 & 83.206 & & & & & & \\
\hline 21 & .562 & 1.406 & 84.611 & & & & & & \\
\hline 22 & .533 & 1.333 & 85.944 & & & & & & \\
\hline 23 & .492 & 1.230 & 87.174 & & & & & & \\
\hline 24 & .465 & 1.162 & 88.336 & & & & & & \\
\hline 25 & .450 & 1.124 & 89.460 & & & & & & \\
\hline 26 & .438 & 1.095 & 90.555 & & & & & & \\
\hline 27 & .400 & 1.000 & 91.556 & & & & & & \\
\hline 28 & .393 & .983 & 92.538 & & & & & & \\
\hline 29 & .368 & .921 & 93.460 & & & & & & \\
\hline 30 & .353 & .883 & 94.342 & & & & & & \\
\hline 31 & .326 & .814 & 95.156 & & & & & & \\
\hline 32 & .303 & .758 & 95.915 & & & & & & \\
\hline 33 & .265 & .664 & 96.578 & & & & & & \\
\hline 34 & .255 & .638 & 97.216 & & & & & & \\
\hline 35 & .241 & .602 & 97.819 & & & & & & \\
\hline 36 & .194 & .486 & 98.305 & & & & & & \\
\hline 37 & .193 & .482 & 98.787 & & & & & & \\
\hline 38 & .175 & .438 & 99.224 & & & & & & \\
\hline 39 & .156 & .389 & 99.614 & & & & & & \\
\hline 40 & .155 & .386 & 100.000 & & & & & & \\
\hline
\end{tabular}


This page intentionally left blank 